\title{
Effects of Ionophores on Ruminal Function of Beef Cattle
}

\author{
Rodrigo da Silva Marques ${ }^{1}$ and Reinaldo Fernandes Cooke ${ }^{2, *(D)}$ \\ 1 Department of Animal and Range Sciences, Montana State University, Bozeman, MT 59717, USA; \\ rodrigo.marques@montana.edu \\ 2 Department of Animal Science, Texas A\&M University, College Station, TX 77843, USA \\ * Correspondence: reinaldocooke@tamu.edu; Tel.: +1-979-458-2703
}

check for

updates

Citation: Marques, R.d.S.; Cooke, R.F. Effects of Ionophores on Ruminal Function of Beef Cattle. Animals 2021, 11, 2871. https://doi.org/10.3390/ ani11102871

Academic Editor: Byeng Ryel Min

Received: 7 August 2021

Accepted: 29 September 2021

Published: 30 September 2021

Publisher's Note: MDPI stays neutral with regard to jurisdictional claims in published maps and institutional affiliations.

Copyright: (c) 2021 by the authors. Licensee MDPI, Basel, Switzerland. This article is an open access article distributed under the terms and conditions of the Creative Commons Attribution (CC BY) license (https:/ / creativecommons.org/licenses/by/ $4.0 /)$.
Simple Summary: Ionophores are an important nutritional tool used to manipulate ruminal fermentation dynamics and improve the efficiency and performance of beef and dairy animals. Ionophores are carboxylic polyether antibiotics naturally produced by an occurring strain of Streptomyces spp. Ionophores modulate the ruminal environment by targeting and altering the metabolism of Grampositive bacteria, resulting in an increased concentration of ruminal propionate and a reduced acetate concentration. Another pronounced effect of ionophores is the mitigation of ruminal proteolysis and the consequent reduction in ammonia synthesis. The purpose of this review is to highlight the impacts of ionophores on ruminal fermentation, leading to an improvement in the efficiency and performance of beef cattle.

Abstract: Ionophores have been widely used in the beef and dairy industry for decades to improve feed efficiency and performance by altering ruminal fermentation dynamics, increasing the level of propionate. Ionophores can also reduce ruminal proteolysis and ammonia synthesis, thus increasing the influx of protein into the small intestine in cattle, leading to improvements in performance and efficiency responses. Ionophores indirectly impact ruminal methanogenesis by decreasing the substrate used to produce methane. Despite the consistent benefits of using ionophores in cattle nutrition, their utilization is under public scrutiny due to concerns related to microbial adaptation. However, there is inconsistent evidence supporting these concerns, whereas ionophores are still an important dietary tool to enhance productivity and profitability in beef production systems.

Keywords: cattle; feed efficiency; ionophores; performance; rumen fermentation

\section{Introduction}

Feed additives are an important dietary tool to enhance efficiency and profitability in grazing and feedlot cattle systems [1,2]. Among feed additives, ionophores are the most studied and used in cattle diets, mainly for altering the ruminal microbiome [3,4], optimizing fermentation routes and reducing the rates of digestive disorders [2,5,6]. Changes in the ruminal environment and fermentation dynamics by using ionophores also improve dietary energy and protein utilization $[3,7,8]$. Ionophores have additional benefits in reducing the formation of foam in the rumen (bloat) and the accumulation of short-chain fatty acids (SCFA), including lactic acid (acidosis), due to the inclusion of rapidly fermentable carbohydrates in the diet $[2,5,6,9]$. Therefore, ionophores have been used to improve performance, ruminal fermentation parameters, and health of beef cattle.

Ionophores are carboxylic polyether antibiotics naturally produced by an occurring strain of Streptomyces spp and provided to beef cattle orally $[9,10]$. Ionophores modulate the ruminal environment by targeting and altering the bacterial metabolism of Gram-positive bacteria, such as cellulolytic, proteolytic, methanogenic, and lactateproducing species [11-13]. Several ionophores (lasalocid, monensin, salinomycin, laidlomycin, and narasin) are available commercially with a similar mechanism of action in the rumen, whereas animal performance might vary depending on dosage, animal, and 
diet $[1,2,5,9,10,14]$. Dietary ionophores can provide the ruminal dynamics with a more efficient fermentation route by altering the ruminal microbiome environment and reducing the substrate for methanogenic bacteria $[1,2,4,14,15]$. Another noticeable effect of dietary ionophores is mitigating ruminal proteolysis and subsequent reduction in ammonia synthesis $[14,16,17]$. Hence, the purpose of this review is to provide an overview of the impacts of ionophores on ruminal fermentation of beef cattle.

\section{Ionophores Mode of Action}

Ionophores are carboxylic polyether antibiotics naturally produced by Streptomyces spp. bacteria with a very similar mechanism of action in the rumen environment. Russell and Strobel [7] reviewed the ionophores' mechanism in the rumen, and provided details on the general properties of ionophores and their mode of action. Ionophores are highly lipophilic molecules [18], and their capacity to adhere to bacteria and protozoa membrane determines the vulnerability of the organisms in the gastrointestinal tract. Adherence is, at least in part, determined by the cell wall structure of the bacteria [3,4]. Grampositive bacteria are absent of protective membrane and, consequently, are more sensitive to ionophores. In turn, Gram-negative bacteria appear to be insensitive to ionophores due to their outer protective membrane, despite such sensitivity mechanisms being poorly understood [19].

Ionophores can interact with metal ions, thereby serving as a carrier for these ions to be transported across the lipid membrane [20]. Most bacteria in the rumen preserve a more alkaline environment by maintaining a high intracellular potassium and a low intracellular sodium concentration [19]. However, the ruminal environment contains high sodium and low potassium, and slightly acidic $\mathrm{pH}$ due to SCFA concentrations [7]. Hence, rumen bacteria rely on the ion gradient balance between sodium and potassium to maintain a healthy intracellular environment. Ionophores are metal/proton antiporters that can exchange $\mathrm{H}+$ for either sodium or potassium $[7,18]$. Once added into the diet, ionophores will insert into the lipid membrane of rumen bacteria, disrupt the intracellular and extracellular ion balance by decreasing intracellular potassium and $\mathrm{pH}$ and increasing intracellular sodium [19]. The rumen bacteria react to this intracellular acidification by activating sodium/potassium and hydrogen ATPase systems, which pump these protons out of the cell [21]. However, these antiporter actions deplete intracellular ATP during the removal of hydrogen ions, reducing cellular viability $[7,19]$. Each ionophore is also selective for specific ions, and this selectivity is an index of ion-binding preference $[9,22]$. Although ionophores share a standard mode of action, differences in selectivity dictate the capacity of the ionophore in achieving effective rumen concentrations and their efficiency in causing bacterial changes (Table 1) [18].

Table 1. Ionophores characteristics and ion-binding selectivity preference ${ }^{1}$.

\begin{tabular}{|c|c|c|c|}
\hline Ionophore & Produced by & Molecular Weight & $\begin{array}{l}\text { Ion-Binding Selectivity } \\
\text { Sequence }\end{array}$ \\
\hline Monensin & Streptomyces cinnamonensins & 671 & $\mathrm{Na}^{+}>\mathrm{K}^{+}, \mathrm{Li}^{+}>\mathrm{Rb}^{+}>\mathrm{Cs}^{+}$ \\
\hline Lasalocid & Streptomyces lasaliensis & 591 & $\mathrm{Ba}^{++}, \mathrm{K}^{+}>\mathrm{Rb}^{+}>\mathrm{Na}^{+}>\mathrm{Cs}^{+}>\mathrm{Li}^{+}$ \\
\hline Narasin & Streptomyces aureofaciens & 765 & $\mathrm{Na}^{+}>\mathrm{K}^{+}, \mathrm{Rb}^{+}, \mathrm{Cs}^{+}, \mathrm{Li}^{+}$ \\
\hline Salinomycin & Streptomyces albus & 751 & $\begin{array}{c}\mathrm{Rb}^{+}, \mathrm{Na}^{+}>\mathrm{K}^{+}>>\mathrm{Cs}^{+}, \mathrm{Sr}^{+}, \mathrm{Ca}^{++}, \\
\mathrm{Mg}^{+}\end{array}$ \\
\hline
\end{tabular}

${ }^{1}$ Adapted from Nagaraja [9].

Bacteria that produce ionophores are naturally insensitive to ionophores, whereas these resistance mechanisms are not well defined [23]. Insensitivity to ionophores appears to essentially result from a failure of these molecules to penetrate the bacterial cell wall, reflecting the presence of a cell membrane or extracellular polysaccharide [24,25]. Accordingly, it was proposed that ionophores preferentially inhibit Gram-positive bacteria over Gram-negative bacteria, given the penetration of these molecules into the cell membrane of 
these Gram-positive bacteria [3]. However, this statement is not valid for all rumen bacteria $[23,25]$. For instance, Butyrivibrio fibrisolvens is a butyric acid-producing Gram-positive bacteria insensitive to dietary ionophores $[9,26]$. Moreover, some Gram-negative bacteria can be initially sensitive to ionophores, and become insensitive after a period of adaptation $[23,27]$. In general, ionophores-sensitive bacteria are predominantly Gram-positive and produce acetic acid, butyric acid, lactic acid, and methane. In turn, ionophore-insensitive bacteria are Gram-negative bacteria that favor the production of succinate and propionate acids (Table 2) $[9,28]$. Despite a growing concern about Gram-positive bacteria becoming adapted and developing insensitivity to ionophores, there is limited evidence supporting this theory, which warrants further investigation $[23,29]$.

Table 2. Sensitivity response of ruminal bacteria to ionophores.

\begin{tabular}{ccc}
\hline Fermentation Products and Species & Gram Type Reaction & Sensitivity to Ionophores \\
\hline Hydrogen and formic acid producers & & \\
Lachnospira multiparus & $\mathrm{Gram}^{+}$ & insensitive \\
Ruminococcus albus & $\mathrm{Gram}^{+}$ & insensitive \\
Ruminococcus flavefaciens & $\mathrm{Gram}^{+}$ & insensitive \\
Butyric acid producers & & \\
Butyvibrio fibrisolvens & $\mathrm{Gram}^{+}$ & insensitive \\
Eubacterium cellulosolvens & $\mathrm{Gram}^{+}$ & sensitive \\
Eubacterium ruminantium & $\mathrm{Gram}^{+}$ & sensitive \\
Lactic acid producers & & \\
Lactobacillus ruminis & $\mathrm{Gram}^{+}$ & sensitive \\
Lactobacillus vitulinis & $\mathrm{Gram}^{+}$ & sensitive \\
Streptococcus bovis & $\mathrm{Gram}^{+}$ & sensitive \\
Propionic and succinic acid producers & & \\
Anaerovibrio lipolytica & $\mathrm{Gram}^{-}$ & insensitive \\
Fibrobacter succinogenes & $\mathrm{Gram}^{-}$ & insensitive \\
Megasphaera elsdenii & $\mathrm{Gram}^{-}$ & insensitive \\
Prevatella Ruminicola & $\mathrm{Gram}^{-}$ & insensitive \\
Ruminobacter amylophilus & $\mathrm{Gram}^{-}$ & insensitive \\
Selenomonas ruminantium & $\mathrm{Gram}^{-}$ & insensitive \\
Succinimonas amylolytica & $\mathrm{Gram}^{-}$ & insensitive \\
Succinivibrio dextrinosolvens & $\mathrm{Gram}^{-}$ & insensitive \\
Ammonia producers & & \\
Clostridium aminophilum & $\mathrm{Gram}^{+}$ & Sensitive \\
Clostridium sticklandii & $\mathrm{Gram}^{+}$ & sensitive \\
Peptostreptococcus anaerobius & $\mathrm{Gram}^{+}$ & sensitive \\
Methane producers & & \\
Methanobrevibacter ruminantium & $\mathrm{Gram}^{-}$ & insensitive \\
Methanobacterium formicum & $\mathrm{Gram}^{-}$ & insensitive \\
Methanosrcina barkeri & $\mathrm{Gram}^{-}$ & Insensitive \\
\hline Adapted from Chen and Wolin & {$\left[9 \mathrm{Rus}^{-}\right.$} &
\end{tabular}

Adapted from Chen and Wolin [27], Russel [19], Nagaraja [9], Russel and Houlihan [23].

\section{Ionophores and Animal Production}

Dietary ionophores are widely used in the beef and dairy industry as a rumen modifier and coccidiostat. Several meta-analyses are available on the effects of ionophores on beef $[1,2,5,10,14,15,28]$ and dairy cattle performance [30]. In a meta-analyses conducted by Duffield et al. [2], monensin consistently decreased dry matter intake (DMI) by $3.1 \%$ and increased average daily gain (ADG) by $2.5 \%$ in feedlot cattle. Consequently, supplementing feedlot cattle with monensin increased feed efficiency by $1.3 \%$ [2]. These results agree with previous research conducted by Goodrich et al. [16], where cattle fed monensin-containing diets gained $1.6 \%$ more and consumed $6.4 \%$ less feed in the feedlot. Nevertheless, the improvement in feed efficiency resultant from ionophores decreased from $8.1 \%$ to $3.5 \%$ over the past 50 years, a consequence of enhanced management, nutrition, and health of feedlot cattle [2]. It is also important to note that several variables influence the difference in performance in trials using ionophores, such as days on feed, ionophore type and 
dose, cattle body weight, forage:concentrate ratio, type of grain fed, and type of cattle evaluated [2,14]. Golder and Lean [13] observed that cattle entering the feedlot at $>275 \mathrm{~kg}$ and fed for a maximum of 100 days had the greatest ADG improvement in response to Lasalocid supplementation. Contrary to this, cattle with an entry weight of $>275 \mathrm{~kg}$ that were fed lasalocid for $>100$ days had an intermediate increase in ADG compared with cattle with an entry weight of $<275 \mathrm{~kg}$, regardless of the number of days on feed [13]. Bretschneider et al. [1] observed a quadratic relationship between the dose of monensin or lasalocid and ADG in beef cattle fed forage-based diets. These authors also observed that the magnitude of the ADG response to dietary ionophores might depend on the forage quality and forage:concentrate ratio of the diet [1]. The ionophores described in this review also increased feed efficiency quadratically without affecting the DMI of grazing animals [1]. Accordingly, Limede et al. [31] reported an increase of $14.8 \%$ in ADG by adding narasin to a forage-based diet, which resulted in heavier animals at the end of $140 \mathrm{~d}$ supplementation period. Beck et al. [32] reported that adding monensin and lasalocid in a corn-based supplement increased ADG of grazing steers. For cattle fed grain-based diets, however, Duffield et al. [2] observed a linear effect of monensin inclusion, where greater doses improved efficiency but reduce intake and ADG response. In the review by Golder and Lean [14], lasalocid increased ADG (by an average of $40 \mathrm{~g} / \mathrm{d}$ ) and feed efficiency, but it did not impact the DMI of feedlot cattle. Therefore, the inclusion of ionophores in forage or grain-based diets is a beneficial management technique to optimize efficiency and performance of beef production systems. Beef producers, however, need to be aware of the differences and particularities of each ionophore to make educated decisions on the inclusion of this dietary tool in cattle diets.

\section{Ionophores and Rumen Fermentation Function}

It is well known that the inclusion of ionophores in the diet increases the feed efficiency and performance of ruminants $[2,29,30]$ by modulating the rumen microbiome and fermentation routes and increasing energy and nitrogen efficiency metabolism $[5,28]$. Although ionophores available in the market have a similar mode of action in the rumen, animal performance and ruminal function may vary depending on dosage, animal, and diet $[1,2,10,14]$. For example, in diets containing a high concentration of readily fermentable carbohydrates (i.e., feedlot diets), ionophores generally influence feed efficiency by improving or maintaining body weight gain and reducing feed intake $[1,2,5,28]$. Similarly, ionophore inclusion in forage-based diets increases cattle body weight gain and feed efficiency, but with similar or increased feed intake [1,31,33-35]. The effects of ionophores on intake might depend on forage quality consumed by cattle, which can impact the passage rate and gut fill, and consequently intake response [1].

The effects observed, at least partially, on animal performance are the response to the changes in ruminal microbiota and fermentation routes (Figure 1) promoted by the inclusion of ionophores in the diet. Approximately 75 to $85 \%$ of energy derived from the feed in the diet is converted to ruminal SCFA, and the remaining energy is lost as heat and methane [36,37]. Furthermore, 60 to $75 \%$ of ruminant's digestible energy comes from ruminal fermentation of carbohydrates, resulting in SCFA, methane, carbon dioxide, ammonia, and microbe cells [36,38]. The predominant SCFA in the rumen are acetate, propionate, and butyrate, and their ruminal proportions are influenced by the diet [38]. In a forage-based diet, the ruminal proportions of acetate, propionate, and butyrate are generally 70:20:10, with an acetate:propionate ratio of 3:1. With a grain-based diet, the ruminal proportion of these SCFA is generally 50:40:10, with an acetate:propionate ratio of 2:1 [38]. 


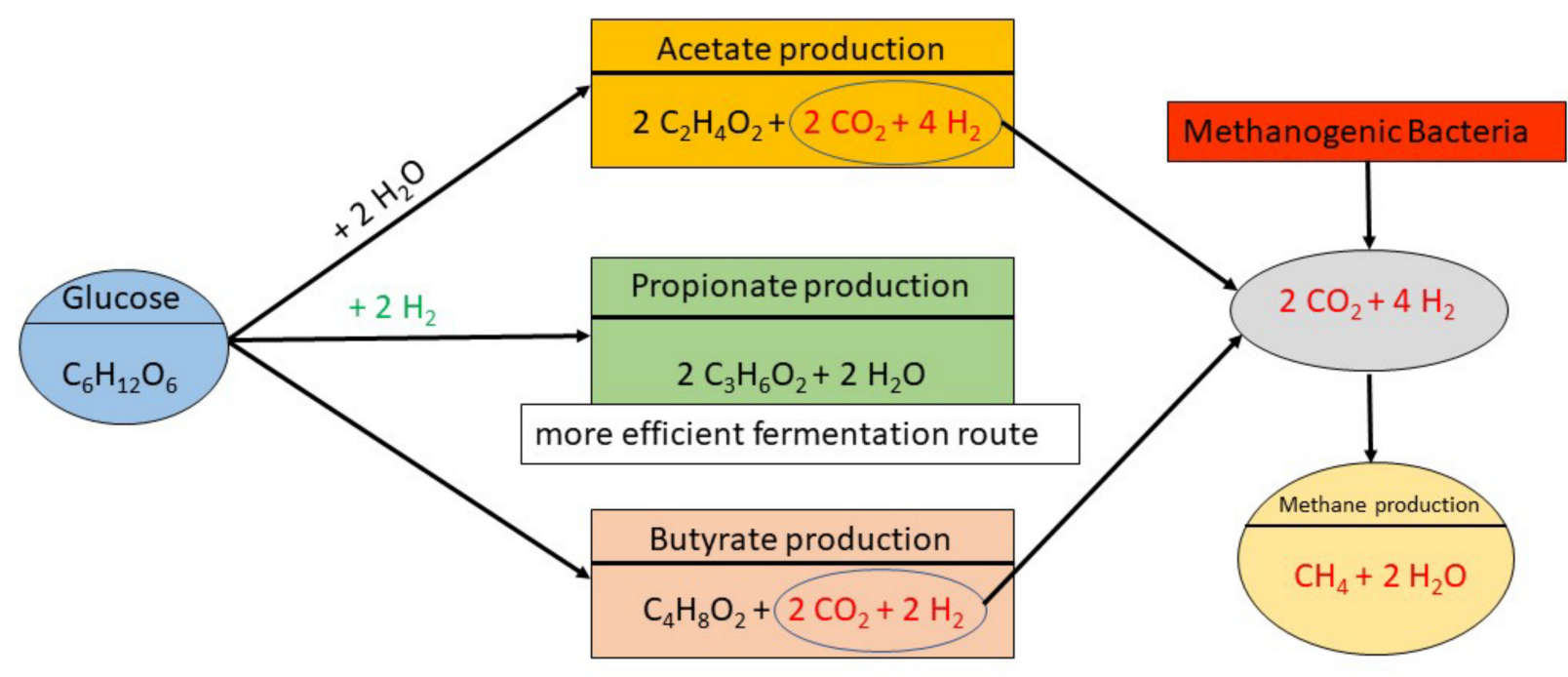

Figure 1. Ruminal fermentation routes and short-chain fatty acids (SCFA) and methane production. Adapted from Bergman [39] and NASEM [40].

Although all SCFA are used efficiently by the ruminant animal, propionate is the only SCFA that serves as a precursor for glucose synthesis. Propionate represents 27 to $54 \%$ of the total glucose synthesized by the liver [40], and for this reason is considered the most important SCFA fermented in the rumen [41]. Furthermore, propionate is a hydrogen sink, but acetate and butyrate are hydrogen sources, and hydrogen is the major substrate for methane formation (Figure 1) [15,42]. Methane represents an energy loss to the animal, ranging from $2 \%$ to $12 \%$ of gross energy intake [15,37]. Therefore, manipulating ruminal fermentation to produce a higher level of propionate and decreasing acetate and butyrate production is positively correlated with greater feed energy utilization and performance $[1,3,7,8,28]$. Additionally, an increase in propionate also mitigates methane production (Figure 1), thus improving energy efficiency obtained from the diet $[1,14,15,28,38]$.

The inclusion of ionophores has constantly increased the ruminal concentration of propionate and reduced acetate in forage $[1,31,33-35,43]$ and grain-based diets $[2,5,14,28]$. Accordingly, Ellis et al. [15] reported an increased proportion of ruminal propionate as the monensin dose increased in feedlot diets. Golder and Lean [14] conducted a meta-analysis to quantify the SCFA profile in beef cattle supplemented with $>200 \mathrm{ppm}$ of lasalocid and showed that ruminal propionate increased by $4.6 \%$ and acetate decreased by $3.2 \%$. Polizel et al. [33] and Limede et al. [31] also reported an enhanced ruminal propionate concentration and reduced acetate and acetate:propionate ratio in beef cattle fed foragebased diets with the addition of narasin (Table 3). Moreover, monensin supplementation of steers consuming bermudagrass hay increased ruminal propionate by $10.4 \%$ and reduced ruminal acetate by $1.7 \%$ [43]. These findings support an improved energy efficiency from an increased ruminal propionate in animals fed ionophores regardless of diet. The energy density of the diet is one of the drivers for differences observed in performance and ruminal fermentation with the inclusion of ionophores in forage or grain-based diets $[1,2,14,16]$. Goodrich et al. [16] summarized that the optimum energy density for the inclusion of monensin in the diet is $2.9 \mathrm{Mcal}$ of metabolizable energy per kg of dry matter. However, when dietary energy is lower or higher than this level, animal performance and feed efficiency responses might be reduced in response to dietary ionophores [16]. 
Table 3. Rumen short-chain fatty acids (SCFA) concentrations (mM/100 mM) in steers receiving forage-based diets supplemented or not (CON, $n=8)$ with narasin (NAR, $n=8)$. CON = no feed additives; NAR = inclusion of 13 ppm of narasin.

\begin{tabular}{|c|c|c|c|c|}
\hline \multirow{2}{*}{ Item } & \multicolumn{2}{|c|}{ Treatments } & \multirow[b]{2}{*}{ SEM } & \multirow[b]{2}{*}{$p$-Value } \\
\hline & $\mathrm{CON}$ & NAR & & \\
\hline \multicolumn{5}{|l|}{ Limede et al. [31] } \\
\hline Acetate & 73.46 & 72.98 & 0.14 & $<0.01$ \\
\hline Propionate & 13.77 & 14.53 & 0.14 & $<0.01$ \\
\hline Butyrate & 9.05 & 8.60 & 0.10 & 0.01 \\
\hline Acetate:Proprionate & 5.39 & 5.01 & 0.05 & $<0.01$ \\
\hline \multicolumn{5}{|l|}{ Polizel et al. [33] } \\
\hline Acetate & 74.21 & 72.71 & 0.16 & $<0.01$ \\
\hline Propionate & 13.83 & 15.82 & 0.13 & $<0.01$ \\
\hline Butyrate & 8.89 & 8.54 & 0.07 & $<0.01$ \\
\hline Acetate:Proprionate & 5.40 & 4.63 & 0.04 & $<0.01$ \\
\hline
\end{tabular}

Improved energetics of rumen fermentation caused by ionophores was demonstrated by the last edition of Nutrient Requirements of Beef Cattle [40], suggesting that dietary metabolizable energy increases by $2.3 \%$ and $1.5 \%$ when monensin or lasalocid are offered to beef cattle, respectively. Accordingly, Rogers and Davis [44] reported that the total SCFA energy produced in the rumen per kilogram of dry matter consumed by steers fed a basal diet of $50 \%$ corn silage and $50 \%$ concentrate was enhanced from $0.852 \mathrm{Mcal} / \mathrm{kg}$ of dry matter for control steers to $1.137 \mathrm{Mcal} / \mathrm{kg}$ of dry matter for steers fed monensin, representing a 33\% increase in digestible ruminal energy. Duffield et al. [30] reported that monensin supplementation to dairy cows effectively reduces blood concentrations of BHBA, acetoacetate, and NEFA and increases blood concentrations of glucose and urea. These findings demonstrate an improvement in the energy status of dairy cows supplemented with monensin. Therefore, ionophores successfully benefit performance by altering ruminal fermentation patterns and the energy status of ruminants.

The effects of ionophores on enhancing the rumen fermentation profile to increase propionate levels were discovered several decades ago, but drawing the principal mechanism of action has been a challenge [3]. For instance, Callaway et al. [45] reported that Butyrivibrio fibrosolvens is an important acetate and butyrate producer, and the capability of monensin to inhibit bacteria of the Butyrivibrio genus might result in improved propionate production. Accordingly, Schären et al. [4] demonstrated that administering monensin to dairy cows significantly decreased the abundance of moderate producers or non-producers of propionate. These authors also observed an increased abundance of succinate- and propionate-producing bacteria (Prevotella and Ruminococcaceae) [4]. Succinate is converted into propionate by ruminal bacteria [46], which explains, at least partially, how ionophores alter ruminal fermentation dynamics.

Ionophores inhibit methanogenesis by lowering the availability of hydrogen and formate, the primary substrates for methanogenic bacteria (Figure 1). A meta-analysis by Appuhamy et al. [47] showed that monensin supplementation reduced methane production by 2 to $15 \%$ in dairy cows and beef cattle, respectively. Schären et al. [4] reported no alteration in the abundance of methanogenic bacteria in the presence of monensin, indicating that the shift of the acetate:propionate ratio caused by ionophores reduces the substrate available to methanogenic bacteria (Figure 1), and thus decreases methane production. Another mechanism that could explain the reduction in methane production is an increase in bacteria species that compete for hydrogen [48] or a decrease in hydrogen production through the inhibition of protozoa [7].

\section{Ionophores and Ruminal Nitrogen Metabolism}

For the ruminant animal, protein and amino acid degradation in the rumen are nutritionally inefficient processes that often produce more ammonia than the bacteria can 
use, representing a loss of dietary nitrogen [49]. Early studies identified that the effects of ionophore supplementation on animal performance and efficiency were a reflection of the changes in ruminal microbiota and fermentation dynamics $[1,2,15]$. In addition, Chalupa et al. [50] suggested that part of the improvements in performance and efficiency from ionophore supplementation are resultant from decreasing ruminal proteolysis, and the accumulation of ammonia and microbial nitrogen. Several in vitro and in vivo studies observed that monensin impacts ruminal nitrogen metabolism by inhibiting deamination and proteolysis $[16,49,51-54]$. Therefore, a greater amount of nitrogen reaches the abomasum from the diet when ionophores are added $[55,56]$.

Muntifering et al. [55] reported that monensin decreased the contribution of bacterial $\mathrm{N}$ and increased the contribution of ruminally undegraded dietary $\mathrm{N}$ to total abomasal N. Faulkner et al. [56] also observed that level of monensin supplementation quadratically decreased ruminal bacterial protein concentrations but increased the ruminal dietary N. According to Russel et al. [57], ionophores inhibit the production of two species of microorganisms, Peptostreptococcus and Clostridium, that have the ability to produce high concentrations of ammonia in the rumen. These species are ionophore-sensitive Grampositive bacteria that require amino acid sources for growth; thus, dietary ionophores limit these species in the rumen, reducing deamination of dietary protein [52,57]. Accordingly, Yang and Russell [49] demonstrated that the decrease in ruminal ammonia concentration resultant from ionophores was related to a 10-fold decrease in ruminal bacteria that use amino acids and peptides as an energy source for growth. However, Golder and Lean [14] reported that administering lasalocid supplementation to beef cattle increased ruminal ammonia concentration, which contrasts the findings in other studies where the ammonia concentration decreased in monensin- or narasin-fed cattle [33,34,49,57]. Polizel et al. [33] demonstrated that administering narasin supplementation to beef cattle fed a forage-based diet for $140 \mathrm{~d}$ reduced the ruminal ammonia concentration by $32 \%$ compared with nonsupplemented beef steers. Soares et al. [34] also reported that supplementing narasin as infrequently as every other day or daily reduced the ruminal ammonia concentration by $22 \%$ and $27 \%$, respectively, compared with non-supplemented steers. The changes induced by dietary ionophores might result in increased ruminal peptide and amino acid concentrations, with a subsequent and consistent reduction in ruminal ammonia concentrations. The increased availability of the peptides and ammonia stimulates the growth of rumen bacteria, which can grow linearly in response to carbohydrate fermentation [58]. Collectively, the use of dietary ionophores alleviates ruminal proteolysis, reduces ammonia synthesis, and increases the influx of protein into the small intestine in cattle, which could explain, at least partially, the improvements in the performance and efficiency of beef cattle.

\section{Ionophores' Persistence}

The effectiveness of ionophores has been documented in grain and forage-based diets $[1,2,14,15,31,33,34]$. However, ionophore use is limited in grazing systems due to concerns regarding depressed intake of supplements, as well as the labor required to provide supplements to cattle in extensive management $[1,59,60]$. The inconsistent intake of supplements by grazing cattle may also influence the effects of ionophores on rumen fermentation function and growth performance $[1,34,43,60]$. Meal size may also enhance the likelihood of feed additive toxicity in grazing animals, particularly if bunk space management is inadequate to prevent overconsumption [61]. Hence, the application of ionophores in grazing systems is not widespread, because most of these operations are not equipped with the resources required (bunks, carrier feed, trucks, labor, etc.) to feed cattle consistently [43].

Research has also examined the effects of ionophores, after withdrawal from the diet, on ruminal fermentation parameters, indicating a residual and long-term effect of these molecules on the proportion of SCFA, methane production, and ionophores-insensitive microbe population [17,34,43,62-64]. Dawson and Boling [62] observed that total ruminal SCFA in heifers supplemented with monensin only returned to basal values within 10 days 
after removing monensin from the diet. Rogers et al. [17] reported a $21.8 \%$ reduction in total SCFA when monensin was included in the diet of wethers for 146 days, whereas total SCFA concentration returned to basal values within $24 \mathrm{~h}$ of monensin withdrawal. Bell et al. [43] reported that total SCFA concentration remained $13.7 \%$ lower for $1 \mathrm{~d}$ in steers previously treated with monensin. By d 4 after monensin withdrawal, total SCFA concentration was similar between monensin-treated and control animals [43]. Nonetheless, these authors reported that the proportion of acetate remained lower, and that of propionate remained greater up to 7 days after monensin withdrawal compared with non-supplemented steers. A similar outcome was reported by Pasqualino et al. [64] in an ruminal environment when narasin was removed from the diet, resulting in greater proportion of propionate until 4 days after narasin withdrawal. These authors did not observe a lasting effect on the proportion of acetate, whereas the acetate:propionate ratio remained lower until day 3 after removing narasin from the diet [65]. Potchoiba et al. [63] reported that monensin maintained changes in propionate concentrations up to 3 days after removing this molecule from the diet. These results might help beef cattle producers schematizing supplementation strategies to optimize rumen fermentation parameters in grazing systems, reducing additional resources required to apply these dietary molecules. Based on this rationale, Soares et al. [34] evaluated the impacts of narasin supplementation frequency on ruminal fermentation patterns of steers fed a forage-based diet. These authors reported that decreasing the frequency of narasin supplementation from daily to every 2 days did not affect propionate, acetate, total SCFA, and acetate:propionate ratios, indicating a residual effect of this molecule in cattle receiving forage-based diets that allows infrequent supplementation to alleviate labor requirements.

It has been suggested that the use of ionophores for an extended period would also impact the persistence efficacy in ruminal fermentation response due to a possible ruminal microbial adaptation to dietary ionophores [17,66,67]. Odongo et al. [67], however, reported that monensin supplementation sustained a 7 to $9 \%$ reduction in methane production of dairy cows for 6 months. Accordingly, other previous studies demonstrated a lasting and consistent effect on ruminal fermentation parameters when monensin was fed to cattle for up to 240 days [17,65,68]. Limede et al. [31] reported increased propionate and total SCFA concentrations and reduced acetate and butyrate concentrations in steers supplemented with narasin in forage-based diets for 140 days. These authors, however, did not observe differences in ruminal fermentation parameters when salinomycin was used in forage-based diets. Other studies have shown that the reduction in ruminal methane production returned to basal levels after 30 days of supplementation [37]. Guan et al. [69] reported that monensin suppressed methane production in both high- and low-concentrate diets, whereas the duration of suppression was longer (3 weeks) when animals were fed a low-concentrate diet than when they were fed a high-concentrate diet. These results suggest that persistent effects of ionophores on ruminal fermentation patterns might be related to the diet composition, ionophore type and dose used. Nevertheless, research is warranted to validate the persistence efficacy of ionophores over a long period on rumen fermentation dynamics.

\section{Conclusions}

Ionophores are the most studied and used feed additives in beef cattle diets, with remarkably consistent evidence on altering the rumen microbiome, optimizing ruminal fermentation towards more efficient routes, reducing the rates of digestive disorders, and mitigating methane production. Differences in ruminal function likely reflect the differences in animal, diet, and type and dose of ionophore used. The effects of ionophores on ruminal fermentation dynamics appear to be consistent even with prolonged feeding periods. Moreover, the lasting impacts of the ionophore on rumen function might aid beef producers in defining nutritional strategies to improve productivity and profitability in cattle systems using this dietary technology. 
Author Contributions: Conceptualization, R.d.S.M. and R.F.C.; Writing-Original draft preparation, R.d.S.M. and R.F.C.; Writing-Review and editing, R.d.S.M. and R.F.C.; supervision, R.F.C. All authors have read and agreed to the published version of this manuscript.

Funding: This research received no external funding.

Conflicts of Interest: The authors declare no conflict of interest.

\section{References}

1. Bretschneider, G.; Elizalde, J.C.; Pérez, F.A. The effect of feeding antibiotic growth promoters on the performance of beef cattle consuming forage-based diets: A Review. Livest. Sci. 2008, 114, 135-149. [CrossRef]

2. Duffield, T.F.; Merrill, J.K.; Bagg, R.N. Meta-analysis of the effects of monensin in beef cattle on feed efficiency, body weight gain, and dry matter intake. J. Anim. Sci. 2012, 90, 4583-4592. [CrossRef]

3. Weimer, P.J.; Stevenson, D.M.; Mertens, D.R.; Thomas, E.E. Effect of monensin feeding and withdrawal on populations of individual bacterial species in the rumen of lactating dairy cows fed high-starch rations. Appl. Microbiol. Biotechnol. 2008, 80, 135-145. [CrossRef]

4. Schären, M.; Drong, C.; Kiri, K.; Riede, S.; Gardener, M.; Meyer, U.; Hummel, J.; Urich, T.; Breves, G.; Dänicke, S. Differential effects of monensin and a blend of essential oils on rumen microbiota composition of transition dairy cows. J. Dairy Sci. 2017, 100, 2765-2783. [CrossRef] [PubMed]

5. Tedeschi, L.O.; Fox, D.G.; Tylutki, T.P. Potential environmental benefits of ionophores in ruminant diets. J. Environ. Qual. 2003, 32, 1591-1602. [CrossRef]

6. Nagaraja, T.G.; Lechtenberg, K.F. Acidosis in feedlot cattle. Vet. Clin. N. Am. Food Anim. Pract. 2007, 23, 333-350. [CrossRef]

7. Russell, J.B.; Strobel, H.J. Effect of ionophores on ruminal fermentation. Appl. Environ. Microbiol. 1989, 55, 1-6. [CrossRef] [PubMed]

8. McGuffey, R.K.; Richardson, L.F.; Wilkinson, J.I.D. Ionophores for dairy cattle: Current status and future outlook. J. Dairy Sci. 2001, 84, E194-E203. [CrossRef]

9. Nagaraja, T.G. Ionophores and antibiotics in ruminants. In Biotechnology in Animal Feeds and Animal Feeding; John Wiley \& Sons, Ltd.: Hoboken, NJ, USA, 1995; pp. 173-204. ISBN 978-3-527-61535-3.

10. Ensley, S. Ionophore use and toxicosis in cattle. Vet. Clin. N. Am. Food Anim. Pract. 2020, 36, 641-652. [CrossRef]

11. Dinius, D.A.; Simpson, M.E.; Marsh, P.B. Effect of monensin fed with forage on digestion and the ruminal ecosystem of steers. J. Anim. Sci. 1976, 42, 229-234. [CrossRef] [PubMed]

12. Richardson, L.F.; Raun, A.P.; Potter, E.L.; Cooley, C.O.; Rathmacher, R.P. Effect of monensin on rumen fermentation in vitro and in vivo. J. Anim. Sci. 1976, 43, 657-664. [CrossRef]

13. Dennis, S.M.; Nagaraja, T.G.; Bartley, E.E. Effect of lasalocid or monensin on lactate production from in vitro rumen fermentation of various carbohydrates. J. Dairy Sci. 1981, 64, 2350-2356. [CrossRef]

14. Golder, H.M.; Lean, I.J. A meta-analysis of lasalocid effects on rumen measures, beef and dairy performance, and carcass traits in cattle. J. Anim. Sci. 2016, 94, 306-326. [CrossRef]

15. Ellis, J.L.; Dijkstra, J.; Bannink, A.; Kebreab, E.; Hook, S.E.; Archibeque, S.; France, J. Quantifying the effect of monensin dose on the rumen volatile fatty acid profile in high-grain-fed beef cattle. J. Anim. Sci. 2012, 90, 2717-2726. [CrossRef]

16. Goodrich, R.D.; Garrett, J.E.; Gast, D.R.; Kirick, M.A.; Larson, D.A.; Meiske, J.C. Influence of monensin on the performance of cattle. J. Anim. Sci. 1984, 58, 1484-1498. [CrossRef]

17. Rogers, M.; Jouany, J.P.; Thivend, P.; Fontenot, J.P. The effects of short-term and long-term monensin supplementation, and its subsequent withdrawal on digestion in sheep. Anim. Feed Sci. Tech. 1997, 65, 113-127. [CrossRef]

18. Pressman, B.C. Biological applications of ionophores. Annu. Rev. Biochem. 1976, 45, 501-530. [CrossRef]

19. Russell, J.B. A Proposed mechanism of monensin action in inhibiting ruminant bacterial growth: Effects on ion flux and protonmotive force. J. Anim. Sci. 1987, 64, 1519-1525. [CrossRef] [PubMed]

20. Ovchinnikov, Y.A. Physico-chemical basis of ion transport through biological membranes: Ionophores and ion channels. Eur. J. Biochem. 1979, 94, 321-336. [CrossRef]

21. Booth, I.R. Regulation of cytoplasmic ph in bacteria. Microbiol. Rev. 1985, 49, 359-378. [CrossRef] [PubMed]

22. Painter, G.R.; Pollack, R.; Pressman, B.C. Conformational dynamics of the carboxylic ionophore lasalocid a underlying cation complexation-decomplexation and membrane transport. Biochemistry 1982, 21, 5613-5620. [CrossRef] [PubMed]

23. Russell, J.B.; Houlihan, A.J. Ionophore resistance of ruminal bacteria and its potential impact on human health. FEMS Microbiol. Rev. 2003, 27, 65-74. [CrossRef]

24. Kim, M.; Felix, T.L.; Loerch, S.C.; Yu, Z. Effect of haylage and monensin supplementation on ruminal bacterial communities of feedlot cattle. Curr. Microbiol. 2014, 69, 169-175. [CrossRef]

25. Kim, M.; Eastridge, M.L.; Yu, Z. Investigation of ruminal bacterial diversity in dairy cattle fed supplementary monensin alone and in combination with fat, using pyrosequencing analysis. Can. J. Microbiol. 2014, 60, 65-71. [CrossRef] [PubMed]

26. Cheng, K.J.; Costerton, J.W. Ultrastructure of butyrivibrio fibrisolvens: A gram-positive bacterium. J. Bacteriol. 1977, 129, 1506-1512. [CrossRef] 
27. Chen, M.; Wolin, M.J. Effect of monensin and lasalocid-sodium on the growth of methanogenic and rumen saccharolytic bacteria. Appl. Environ. Microbiol. 1979, 38, 72-77. [CrossRef]

28. Azzaz, H.H.; Murad, H.A.; Morsy, T.A. Utility of ionophores for ruminant animals: A review. Asian J. Anim. Sci. 2015, 9, 254-265. [CrossRef]

29. Duffield, T.F.; Sandals, D.; Leslie, K.E.; Lissemore, K.; McBride, B.W.; Lumsden, J.H.; Dick, P.; Bagg, R. Efficacy of monensin for the prevention of subclinical ketosis in lactating dairy cows. J. Dairy Sci. 1998, 81, 2866-2873. [CrossRef]

30. Duffield, T.F.; Rabiee, A.R.; Lean, I.J. A meta-analysis of the impact of monensin in lactating dairy cattle. part 1 . metabolic effects. J. Dairy Sci. 2008, 91, 1334-1346. [CrossRef]

31. Limede, A.C.; Marques, R.S.; Polizel, D.M.; Cappellozza, B.I.; Miszura, A.A.; Barroso, J.P.R.; Storti Martins, A.; Sardinha, L.A.; Baggio, M.; Pires, A.V. Effects of supplementation with narasin, salinomycin, or flavomycin on performance and ruminal fermentation characteristics of bos indicus nellore cattle fed with forage-based diets. J. Anim. Sci. 2021, 99. [CrossRef]

32. Beck, P.; Galyen, W.; Galloway, D.; Kegley, E.B.; Rorie, R.; Hubbell, D.; Tucker, J.; Hess, T.; Cravey, M.; Hill, J.; et al. Effect of supplementation of developing replacement heifers with monensin or bambermycins on gain and pregnancy rates. Prof. Anim. Sci. 2016, 32, 619-626. [CrossRef]

33. Polizel, D.M.; Cappellozza, B.I.; Hoe, F.; Lopes, C.N.; Barroso, J.P.; Miszura, A.; Oliveira, G.B.; Gobato, L.; Pires, A.V. Effects of narasin supplementation on dry matter intake and rumen fermentation characteristics of bos indicus steers fed a high-forage diet. Transl. Anim. Sci. 2020, 4, 118-128. [CrossRef] [PubMed]

34. Soares, L.C.B.; Marques, R.S.; Pires, A.V.; Cruz, V.A.; Limede, A.C.; Maia, K.S.; Baggio, M.; Barroso, J.P.R.; Biava, J.S.; Ferreira, E.M.; et al. Effects of narasin supplementation frequency on intake, ruminal fermentation parameters, and nutrient digestibility of bos indicus nellore steers fed with forage-based diets. Transl. Anim. Sci. 2021. [CrossRef]

35. DelCurto, T.; Earley, A.; May, T.; Nichols, W. Comparison of bambermycins, lasalocid, and monensin on the nutritional physiology of beef cattle consuming concentrate and forage base diets. In Special Report 991; EOARC Annual Report; Agricultural Experiment Station, Oregon State University: Corvallis, OR, USA, 1999.

36. Sutton, J.D. Carbohydrate fermentation in the rumen-Variations on a theme. P. Nutr. Soc. 1979, 38, 275-281. [CrossRef]

37. Johnson, K.A.; Johnson, D.E. Methane emissions from cattle. J. Anim. Sci. 1995, 73, 2483-2492. [CrossRef]

38. Wolin, M.J.; Miller, T.L.; Stewart, C.S. Microbe-microbe interactions. In The Rumen Microbial Ecosystem; Hobson, P.N., Stewart, C.S., Eds.; Springer: Dordrecht, The Netherlands, 1997; pp. 467-491. ISBN 978-94-009-1453-7.

39. Bergman, E.N. Energy contributions of volatile fatty acids from the gastrointestinal tract in various species. Physiol. Rev. 1990, 70, 567-590. [CrossRef] [PubMed]

40. NASEM. National Academies of Sciences, Engineering and Medicine. Nutrient Requirements of Beef Cattle; Eighth Revised Edition; The National Academies Press: Washington, DC, USA, 2016. ISBN 978-0-309-31702-3.

41. Huntington, G.B. Starch utilization by ruminants: From basics to the bunk. J. Anim. Sci. 1997, 75, 852-867. [CrossRef]

42. Wolin, M.J. A theoretical rumen fermentation balance. J. Dairy Sci. 1960, 43, 1452-1459. [CrossRef]

43. Bell, N.L.; Anderson, R.C.; Callaway, T.R.; Franco, M.O.; Sawyer, J.E.; Wickersham, T.A. Effect of monensin inclusion on intake, digestion, and ruminal fermentation parameters by bos taurus indicus and bos taurus taurus steers consuming bermudagrass hay. J. Anim. Sci. 2017, 95, 2736-2746. [CrossRef]

44. Rogers, J.A.; Davis, C.L. Rumen volatile fatty acid production and nutrient utilization in steers fed a diet supplemented with sodium bicarbonate and monensin. J. Dairy Sci. 1982, 65, 944-952. [CrossRef]

45. Callaway, T.R.; Adams, K.A.; Russell, J.B. The ability of "low g + c gram-positive" ruminal bacteria to resist monensin and counteract potassium depletion. Curr. Microbiol. 1999, 39, 226-230. [CrossRef]

46. Koike, S.; Kobayashi, Y. Fibrolytic rumen bacteria: Their ecology and functions. Asian Austral. J. Anim. 2009, 22, 131-138. [CrossRef]

47. Appuhamy, J.A.D.R.N.; Strathe, A.B.; Jayasundara, S.; Wagner-Riddle, C.; Dijkstra, J.; France, J.; Kebreab, E. Anti-methanogenic effects of monensin in dairy and beef cattle: A meta-analysis. J. Dairy Sci. 2013, 96, 5161-5173. [CrossRef] [PubMed]

48. Morvan, B.; Bonnemoy, F.; Fonty, G.; Gouet, P. Quantitative determination of H2-utilizing acetogenic and sulfate-reducing bacteria and methanogenic archaea from digestive tract of different mammals. Curr. Microbiol. 1996, 32, 129-133. [CrossRef]

49. Yang, C.M.J.; Russell, J.B. Effect of monensin on the specific activity of ammonia production by ruminal bacteria and disappearance of amino nitrogen from the rumen. Appl. Environ. Microbiol. 1993. [CrossRef] [PubMed]

50. Chalupa, W.; Corbett, W.; Brethour, J.R. Effects of monensin and amicloral on rumen fermentation. J. Anim. Sci. 1980, 51, 170-179. [CrossRef] [PubMed]

51. Whetstone, H.D.; Davis, C.L.; Bryant, M.P. Effect of monensin on breakdown of protein by ruminant microorganisms in vitro. J. Anim. Sci. 1981, 53, 803-809. [CrossRef] [PubMed]

52. Paster, B.J.; Russell, J.B.; Yang, C.M.J.; Chow, J.M.; Woese, C.R.; Tanner, R.Y.R. Phylogeny of the ammonia-producing ruminal bacteria Peptostreptococcus Anaerobius, Clostridium Sticklandii, and Clostridium Aminophilum Sp. Nov. Int. J. Syst. Evol. Microbiol. 1993, 43, 107-110. [CrossRef] [PubMed]

53. Chen, G.J.; Russell, J.B. Effect of monensin and a protonophore on protein degradation, peptide accumulation, and deamination by mixed ruminal microorganisms in vitro. J. Anim. Sci. 1991, 69, 2196-2203. [CrossRef] [PubMed]

54. Haïmoud, D.A.; Vernay, M.; Bayourthe, C.; Moncoulon, R. Avoparcin and monensin effects on the digestion of nutrients in dairy cows fed a mixed diet. Can. J. Anim. Sci. 1995, 75, 379-385. [CrossRef] 
55. Muntifering, R.B.; Theurer, B.; Noon, T.H. Effects of monensin on site and extent of whole corn digestion and bacterial protein synthesis in beef steers. J. Anim. Sci. 1981, 53, 1565-1573. [CrossRef]

56. Faulkner, D.B.; Klopfenstein, T.J.; Trotter, T.N.; Britton, R.A. Monensin effects on digestibility, ruminal protein escape and microbial protein synthesis on high-fiber diets. J. Anim. Sci. 1985, 61, 654-660. [CrossRef]

57. Russell, J.B.; Strobel, H.J.; Chen, G.J. Enrichment and isolation of a ruminal bacterium with a very high specific activity of ammonia production. Appl. Environ. Microbiol. 1988, 54, 872-877. [CrossRef]

58. Argyle, J.L.; Baldwin, R.L. Effects of amino acids and peptides on rumen microbial growth yields. J. Dairy Sci. 1989, 72, $2017-2027$. [CrossRef]

59. Davenport, R.W.; Galyean, M.L.; Branine, M.E.; Hubbert, M.E. Effects of a monensin ruminal delivery device on daily gain, forage intake and ruminal fermentation of steers grazing irrigated winter wheat pasture. J. Anim. Sci. 1989, 67, 2129-2139. [CrossRef] [PubMed]

60. Cappellozza, B.I.; Lasmar, P.V.F.; Reis, F.T.; Oliveira, L.; Hoe, F.; Boehler, R.M.; Leibovich, J.; Starkey, R.; Simas, J.; Cooke, R.F. Effects of supplement type and narasin inclusion on supplement intake by bos indicus beef bulls grazing a warm-season forage. Transl. Anim. Sci. 2019, 3, 263-273. [CrossRef]

61. Horn, G.W. Growing Cattle on Winter Wheat Pasture: Management and herd health considerations. Vet. Clin. N. Am.-Food Anim. 2006, 22, 335-356. [CrossRef]

62. Dawson, K.A.; Boling, J.A. Monensin-resistant bacteria in the rumens of calves on monensin-containing and unmedicated diets. Appl. Environ. Microbiol. 1983, 46, 160-164. [CrossRef] [PubMed]

63. Potchoiba, M.J.; Nocerini, M.R.; Carlson, J.R.; Breeze, R.G. Effect of energy or protein supplements containing monensin on ruminal 3-methylindole formation in pastured cattle. Am. J. Vet. Res. 1984, 45, 1389-1392.

64. Pasqualino, L.F.; Oliveira, G.B.; Miszura, A.A.; Barroso, J.P.R.; Limede, A.C.; Sardinha, L.A.; Biava, J.S.; Ferreira, E.M.; Pires, A.V.; Polizel, D.M. Residual effect of narasin on ruminal fermentation characteristics in lambs. Livest. Sci. 2020, 240, 104141. [CrossRef]

65. Davies, A.; Nwaonu, H.N.; Stanier, G.; Boyle, F.T. Properties of a novel series of inhibitors of rumen methanogenesis; in vitro and in vivo experiments including growth trials on 2,4-bis (Trichloromethyl)-Benzo [1,3]Dioxin-6-Carboxylic Acid. Brit. J. Nutr. 1982, 47, 565-576. [CrossRef] [PubMed]

66. Klein, G.; Franz, C.M.A.P. Chapter 9 The farm animal as potential reservoir of antibiotic resistant bacteria in the food chain. In Biology of Growing Animals; Holzapfel, W.H., Naughton, P.J., Pierzynowski, S.G., Zabielski, R., Salek, E., Eds.; Microbial Ecology in Growing Animals; Elsevier: Amsterdam, The Netherlands, 2005; Volume 2, pp. 191-207.

67. Odongo, N.E.; Bagg, R.; Vessie, G.; Dick, P.; Or-Rashid, M.M.; Hook, S.E.; Gray, J.T.; Kebreab, E.; France, J.; McBride, B.W. Longterm effects of feeding monensin on methane production in lactating dairy cows. J. Dairy Sci. 2007, 90, 1781-1788. [CrossRef] [PubMed]

68. Mbanzamihigo, L.; van Nevel, C.; Demeyer, D. Essai sur l'adaptation de la fermentation ruminale au monensin. Reprod. Nutr. Dev. 1995, 35, 353-365. [CrossRef] [PubMed]

69. Guan, H.; Wittenberg, K.M.; Ominski, K.H.; Krause, D.O. Efficacy of ionophores in cattle diets for mitigation of enteric methane. J. Anim. Sci. 2006, 84, 1896-1906. [CrossRef] 